\title{
Cardiovascular Diseases in Children -Oral Findings and Dental Treatment Approaches
}

\author{
Ozge Gogce, Secil Caliskan*, Nuray Tuloglu and Sule Bayrak \\ Department of Pediatric Dentistry, Eskisehir Osmangazi University, Turkey
}

*Corresponding author: Secil Caliskan, Assistant Professor, Department of Pediatric Dentistry, Faculty of Dentistry, Eskisehir Osmangazi University, Eskisehir, Turkey

\begin{abstract}
Oral and dental health is of vital importance in children with cardiovascular system disease. Congenital and acquired heart diseases make oral treatment complicate in children and increase the risk of infective endocarditis [1]. The dentists main aim in children with heart disease should be to prevent infective endocarditis, to maintain periodontal health and to ensure a well oral hygiene. In these children, medical history should be taken in detail before dental treatment. Consult with the pediatrician and inform about the condition of the disease and the drugs used recently. Consideration should be given, and antibiotic prophylaxis should be evaluated consultation to in the treatment planning of children with heart disease. In these children, dental treatments should be performed quickly and effectively, and family awareness should be given importance [1-3]. In this review, common oral findings related to cardiovascular system diseases will be discussed and the precautions and treatment approaches of dentist will be mentioned [4].
\end{abstract}

Keywords: Endocarditis, heart diseases, intraoral findings, pediatric dentistry

\section{Review}

Almost all of the heart diseases seen in children are congenital. The most common structural congenital heart diseases are; ventricular septal defect, patent ductus arteriosus, atrial septal defect, fallot tetralogy, pulmonary stenosis, aortic coarctation, aortic stenosis and transposition of the great arteries. Large defects are surgically closed in the first years of life, and some defects may require complex surgical treatment and eventually transplantation. Acquired heart diseases such as myocarditis and infected endocarditis are the cause of disability and death in children [5]. Oral and dental health may be insufficient in children with congenital heart disease. The reasons for this; chronic vomiting in children up to one-year, dry mouth due to drugs used, neglect of oral care due to cardiac problems as the primary priorities of families [1]. Poor oral hygiene in children with heart disease may pose a risk for bacteremia. Infective endocarditis can result with severe valvular dysfunction, dehiscence, congestive heart disease and various embolisms leading to death. In the long term, it may cause cardiac valve damage and prosthetic regeneration of the heart valve [1,6-8].

\section{Oral findings}

Oral findings in children with cardiovascular disease include cyanotic gingivitis, stomatitis, glossitis, mucositis, cleft lip and palate, clefts in the tongue, the fungiform and filiform papilla of the tongue becoming dark red [5,9]. In addition, enamel hypoplasia, high incidence of caries, delays in teeth exfoliation, periodontal diseases and intrinsic discolorations are observed $[5,9,10]$. In particular, discolorations in permanent teeth occur due to the ingestion of blood and blood products by drugs, increased caries activity and poor oral hygiene [5]. Poor oral hygiene, use of drugs, inadequate food and mineral consumption are effective risk factors for the onset of periodontal disease in children with congenital cardiovascular disease [11,12]. Pourmoghaddas et al. [12] reported that children with congenital heart disease had significantly higher periodontitis than healthy children and that periodontal disease caused endocarditis risk. Al Alousi et al. [13] reported that the rate of development of enamel defects was high in patients with ventricular septal defect and was observed due to malnutrition. The researchers stated that nutrient elements may affect the epithelial 
cell function and mineralization process and prepare the ground for defect formation in enamel hypoplasia [13]. In Fallot Tetralogy, wrinkled tongue is observed as an oral finding [1].

\section{Infective endocarditis}

Infective endocarditis is a rare disease that results in high morbidity and mortality, with an annual incidence of 0.05 $0.12 / 1000$ in children $[3,14,15]$. Turbulent blood flow observed in heart diseases leads to endothelial injury, resulting in storage of platelets and fibrin on the endothelial surface [15]. As a result, non-bacterial thrombotic endocarditis occurs and bacteremia results in the adhesion of bacteria to this injured endocardium and proliferation in vegetation leading to infective endocarditis. Therefore, some heart diseases pave the way for the development of infective endocarditis [14,15]. Invasive dental procedures, gastrointestinal and genitourinary systems related operations may cause bacteremia and infective endocarditis [15].

\section{Bacteremia in dental procedures}

In children, oral flora changes and streptococci (alpha hemolytic streptococci), actinomyces and privately species increase after infancy and begins to resemble adult flora. Healthy children have streptococci, staphylococci, neissera and haemophilus species, while older children have bacteria such as capnocytophaga and aggregatibacter actinomycetemcomitans, which cause periodontal disease [15]. The host's response to dental plaque due to poor oral hygiene is gingivitis. When this inflammation develops, bacterial colonies may become involved in the gum capillary circulation due to thinning and ulceration. Therefore, there is a risk of bacteremia even in minimal procedures such as daily tooth brushing The frequency of bacteremia after toothbrushing and flossing has been reported to be $20-68 \%, 20-40 \%$ after tooth cleaning with toothpicks, 7-50\% after mouth rinsing, and 7-51\% after chewing food [3]. In addition, 10-100\% after tooth extraction, 36-88\% after periodontal surgery, 8-80\% after removal of dental plaque, 9-32\% after plastic matrix placement, $20 \%$ after endodontic procedures have been reported to develop bacteremia [3]. Good oral hygiene and prevention from diseases (such as gingivitis, tooth decay) are important to minimize the risk of bacteremia [15]. The use of amoxicillin in the selection of antibiotics in dental procedures has been shown to have a statistically significant effect on reducing the incidence and duration of bacteremia.

While previous American Heart Association (AHA) guidelines recommend antibiotic prophylaxis for all dental interventions that may cause bleeding, this recommendation has been altered since there is no evidence that this is a predictive symptom of bacteremia when bleeding occurs during dental procedures [3]. In the latest guidelines published by AHA, it was decided to administer prophylactic antibiotics only to the highest-risk group before invasive dental procedures [3] (Table 1). Prophylactic antibiotic administration is recommended only if high-risk patients are scheduled for an operation to the gingival tissue or the periapical region of the tooth, or if there is a risk of mucosal perforation. Routine injections of anesthetic agents, x-rays, removable dental prostheses, orthoses, orthodontic material placement, prosthesis matching, primary tooth extraction, antibiotic prophylaxis are not recommended in uninfected tissue [3]. Antibiotic prophylaxis should be given 30-60 minutes before the procedure. However, it can be given within 2 hours after the procedure if it is not given before the procedure [3]. In patients using oral anticoagulants, intramuscular injection should be avoided, and oral antibiotics should be preferred. Clindamycin, clarithromycin, azithromycin should be given to patients who routinely use antibiotics as they may be resistant to penicillin and ampicillin [3]. These patients should receive dental treatment 10 days after antibiotic treatment to normalize oral flora. In patients receiving intravenous antibiotic therapy, the antibiotic dose should be adjusted 30-60 minutes before dental intervention $[3,16]$ (Tables 1\&2).

Table 1: High-risk patients in whom infective endocarditis prophylaxis is recommended [16].

\begin{tabular}{|c|}
\hline Prosthetic heart valves (bioprosthesis, homograft valves) \\
\hline Cases with previous endocarditis \\
\hline $\begin{array}{c}\text { Complex cyanotic congenital heart diseases (single ventricle, } \\
\text { transposition, tetralogy of Fallotfallot) }\end{array}$ \\
Surgical pulmonary shunting \\
\hline Congenital heart diseases (despite of ASD) \\
\hline Acquired heart diseases (rheumatic valve diseases) \\
\hline Hypertrophic cardiomyopathy \\
\hline Mitral valve prolapse (with insufficiency and / or valve thickening) \\
\hline
\end{tabular}

Table 2: Antibiotic prophylaxis recommended before dental procedures [16].

\begin{tabular}{|c|c|c|c|}
\hline & Antibiotic & $\begin{array}{l}\text { Child Dose } \\
\text { (Single Dose) }\end{array}$ & $\begin{array}{l}\text { Adult Dose } \\
\text { (Single Dose) }\end{array}$ \\
\hline $\begin{array}{l}\text { Able to take oral } \\
\text { medication }\end{array}$ & Amoxicillin & $\begin{array}{c}50 \mathrm{mg} / \mathrm{kg}, 1 \\
\text { hour ago }\end{array}$ & $\begin{array}{c}2 \text { gr, } 1 \text { hour } \\
\text { before } \\
\text { procedure }\end{array}$ \\
\hline \multirow{2}{*}{$\begin{array}{l}\text { Unable to take } \\
\text { oral medication }\end{array}$} & Ampicillin & $\begin{array}{l}50 \mathrm{mg} / \mathrm{kg} \\
\text { IM or IV, } 30 \\
\text { min before } \\
\text { procedure }\end{array}$ & 2 gr IM or IV \\
\hline & $\begin{array}{l}\text { Cefazolin/ } \\
\text { Ceftrixsone }\end{array}$ & $\begin{array}{l}50 \mathrm{mg} / \mathrm{kg} \\
\text { IM or IV, } 30 \\
\text { min before } \\
\text { procedure }\end{array}$ & $\begin{array}{c}1 \text { gr IM or IV, } \\
30 \text { min before } \\
\text { procedure }\end{array}$ \\
\hline \multirow{3}{*}{$\begin{array}{c}\text { Allergic to } \\
\text { Penicillin } \\
\text { penicillin \& } \\
\text { able to take oral } \\
\text { medication }\end{array}$} & $\begin{array}{l}\text { Cephalexin/ } \\
\text { Cefadroxyl }\end{array}$ & $\begin{array}{c}50 \mathrm{mg} / \mathrm{kg}, 1 \\
\text { hour before } \\
\text { procedure }\end{array}$ & $\begin{array}{l}2 \text { gr, } 1 \text { hour } \\
\text { before } \\
\text { procedure }\end{array}$ \\
\hline & Clindamycin & $20 \mathrm{mg} / \mathrm{kg}$ & $600 \mathrm{mg}$ \\
\hline & $\begin{array}{l}\text { Azithromycin/ } \\
\text { Clarithromycin }\end{array}$ & $20 \mathrm{mg} / \mathrm{kg}$ & $500 \mathrm{mg}$ \\
\hline \multirow{2}{*}{$\begin{array}{c}\text { Allergic to } \\
\text { Penicillin } \\
\text { penicillin \& } \\
\text { unable to take } \\
\text { oral medication }\end{array}$} & Cefazolin & $\begin{array}{l}25 \mathrm{mg} / \mathrm{kg} \\
\text { IM or IV, } 30 \\
\text { min before } \\
\text { procedure }\end{array}$ & $\begin{array}{c}1 \text { gr IM or IV, } \\
30 \text { min before } \\
\text { procedure }\end{array}$ \\
\hline & Clindamycin & $\begin{array}{c}20 \mathrm{mg} / \mathrm{kg} \mathrm{IM} \\
\text { or IV }\end{array}$ & $600 \mathrm{mg}$ IM or IV \\
\hline
\end{tabular}

\section{Dentist approach}

Patients with cardiovascular disease should be consulted with their doctors. Deciding on premedication, preoperative antibiotic requirements, anesthetic selection and surgical procedures should be decided in accordance with the recommendations of 
the physician of patient. In children diagnosed with cardiovascular disease, a preventive program including nutritional advice, fluoride therapy, fissure sealants and oral hygiene should be applied [1]. Arrhythmia due to endogenous catecholamines triggered by stress, fear and pain may develop during dental procedures, and patients who are prone to arrhythmia should be closely monitored [3]. Antibiotic prophylaxis should be performed in high-risk patients if a procedure is planned for the gingival tissue or the periapical region of the tooth, or if there is a risk of mucosal perforation [3]. Dental procedures in high and medium risk groups should not exceed the treatment of deep dentine caries. Direct pulp capping, pulpotomy and root canal treatments are not indicated because they increase the risk of bacterial endocarditis. In very deep decayed teeth, the treatment option should be extraction [1].

\section{Conclusion}

In children with cardiovascular disease, the risk of infectious endocarditis and bacteremia due to the risk of fatal outcome of the heart valve is very important in terms of oral and dental health in these patients. It is very important for dentists to consult with their physician before dental procedures in children with heart disease, and to take prophylaxis needs and stress tolerances of their patients by writing. These children and their families should be adequately informed about oral hygiene. In this way, the risk of bacteremia, even in oral cleaning procedures such as chewing and brushing, can prevent infective endocarditis [1].

\section{References}

1. Bozdoğan DHE, Aktören O (1996) Oral and dental health in children with heart disease.

2. da Silva DB, IP Souza, MC Cunha (2002) Knowledge, attitudes and status of oral health in children at risk for infective endocarditis. Int J Paediatr Dent 12(2): 124-131.

3. Wilson W, Taubert KA, Gewitz M, Lockhart PB, Baddour LM, et al. (2007) Prevention of infective endocarditis: guidelines from the American Heart Association: a guideline from the American Heart Association Rheumatic Fever, Endocarditis, and Kawasaki Disease Committee, Council on Cardiovascular Disease in the Young, and the Council on
Clinical Cardiology, Council on Cardiovascular Surgery and Anesthesia, and the Quality of Care and Outcomes Research Interdisciplinary Working Group. Circulation 116(15): 1736-1754.

4. Ekinci AP, C Baykal (2012) Sistemik Hastaliklarda ve Sendromlarda Oral Mukoza/Oral Mucosa in Systemic Diseases and Syndromes. Turkderm 46(2): 96.

5. Pedodontics Department Lecture Notes: Intraoral findings and dental approach of systemic diseases in children, EOUDH, Faculty, Editor.

6. Al-Karaawi Z (2001) Dental procedures in children with severe congenital heart disease: a theoretical analysis of prophylaxis and nonprophylaxis procedures. Heart 85(1): 66-68.

7. Balmer R, FA Bu Lock (2003) The experiences with oral health and dental prevention of children with congenital heart disease. Cardiology in the Young 13(5): 439-443.

8. Bulat DC, MJ Kantoch (2003) How much do parents know about their children's heart condition and prophylaxis against endocarditis? The Canadian journal of cardiology 19(5): 501-506.

9. El-Hawary YM (2014) Deciduous teeth structure changes in congenital heart disease: ultrastructure and microanalysis. Interventional Medicine and Applied Science 6(3): 111-117.

10. Hallett KB, Radford DJ, Seow WK (1992) Oral health of children with congenital cardiac diseases: a controlled study. Pediatric dentistry 14(4): 225-230.

11. Stecksén Blicks C (2004) Dental caries experience in children with congenital heart disease: a case-control study. International journal of paediatric dentistry 14(2): 94-100.

12. Pourmoghaddas Z, Meskin M, Sabri M, Norousali TMH, Najafi T (2018) Dental Caries and Gingival Evaluation in Children with Congenital Heart Disease. Int J Prev Med 9: 52.

13. Al Alousi WS, NO AL Etbi (2011) Enamel defects in relation to nutritional status among a group of children with congenital heart disease (Ventricular septal defect). Journal of baghdad college of dentistry 23(3): 124-129.

14. Aypar E (2016) Dental Health and Treatment in Pediatric Heart Diseases. Journal of Clinical Pediatric Dentistry-Special Topics 2(2): 51-56.

15. Baltimore RS (2015) Infective Endocarditis in Childhood: 2015 Update: A Scientific Statement from the American Heart Association. Circulation 132(15): 1487-515.

16. Association TK Infective endocarditis prophylaxis recommendations.

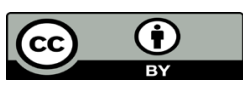

This work is licensed under Creative Commons Attribution 4.0 License

To Submit Your Article Click Here: Submit Article

DOI: $10.32474 /$ IPDOAJ.2020.03.000169

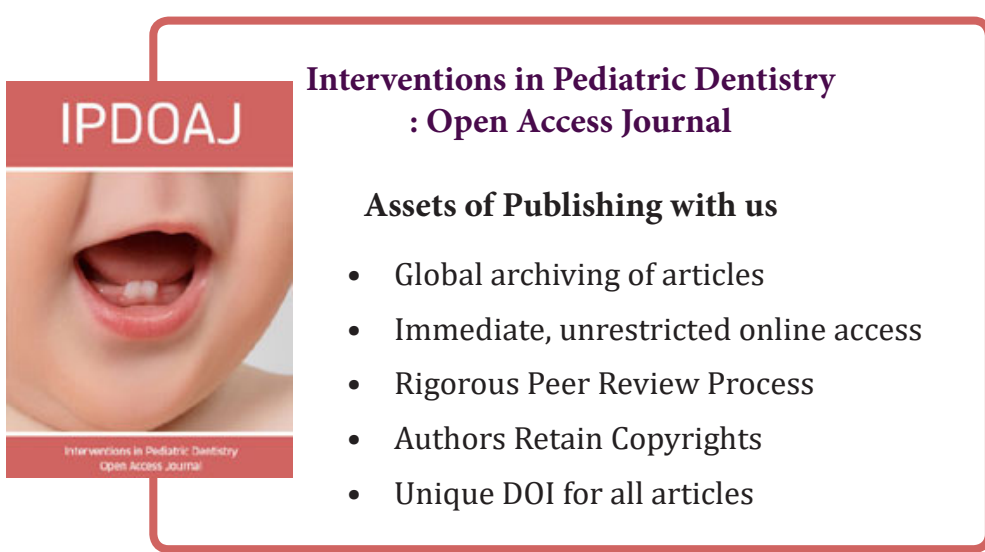

